\title{
ПІДГОТОВКА МАЙБУТНЬОГО ВЧИТЕЛЯ ПОЧАТКОВОЇ ШКОЛИ ДО ВИКЛАДАННЯ ПРЕДМЕТА “ОСНОВИ ЗДОРОВ' Я”
}

3. Kamalov, R.R. (2010). Informacionno pedagogicheskij resurs kak ob'ekt sovremennoj pedagogiki [Information pedagogical resource as an object of modern pedagogy]. Glazov, 195p. [in Russian].

4. Maslov, V.I. (2004). Strategicheskoe upravlenie personalom $v$ uslovijah jeffektivnoj organizacii kultury [Strategic personnel management in the conditions of effective organization of culture]. Moscow: Finpress, 288p. [in Russian].

5. Ovcharuk, O.V. (2003). Kompetentnosti jak kljuch do formuvannja zmistu osviti [Competence as the key to the formation of the content of education]. Strategy of reforming education in Ukraine. Kyiv: K.I.S., 295p. [in Ukrainian].
6. Raven, J. (2002). Kompetentnost v sovremennom obshhestve [Competence in Modern Society]. Moscow: Kohito Center, 218p. [in Russian].

7. Sosnin, O.V. (2012). Informacijno-komunikativna kompetentnist gromadjanina $\mathrm{v}$ procesah formuvannja gromadjanskogo suspilstva [Informational and communicative competence of a citizen in the processes of forming a civil society]. Veche, no. 20 (329), pp. 22 29. [in Ukrainian].

8. Bloom, B. (1994). Reflections on the Development and Use of the Taxonomy. In Anderson, L. Sosniak, L (Eds.) Bloom's Taxonomy: A Forty-Year Retrospective. Chicago: The National Society for the Study of Education. pp.1-8. [in English].

Стаття надійшла до редакції 21.03.2018

УДК 378.011.3 - 051:373.3:613

DOI:

Галина Ковальчук, кандидат біологічних наук, дочент кафедри анатомії, фізіології та валеології Віра Кавчак, старший викладач кафедри біологї та хімії Дрогобицького державного педагогічного університету імені Івана Франка

\section{ПІДГОТОВКА МАЙБУТНЬОГО ВЧИТЕЛЯ ПОЧАТКОВОЇ ШКОЛИ ДО ВИКЛАДАННЯ ПРЕДМЕТА “ОСНОВИ ЗДОРОВ'Я”}

У статті розглянуто актуальні питання підготовки студентів педагогічних університетів до викладання предмета “Основи здоров'я” у початковій школі. Охарактеризовано роль дисципліни “Методика вивчення валеології, основ безпеки життєдіяльності у початковій школі" у особистісно-професійному становленні майбутніх педагогів, здатних ефективно формувати здоров'язбережувальну компетентність молодиих школярів. Акиентовано увагу на доиільності застосування у иуьому процесі інтерактивних технологій навчання.

Ключові слова: підготовка; початкова школа; основи здоров'я; здоров'язбережувальна компетентність; інтерактивні технології.

תim. 6.

Halyna Kovalchuk, Ph.D.(Biology), Associate Professor of the Anatomy, Physiology and Valeology Department Vira Kavchak, Senior Lecturer of the Biology and Chemistry Department Drohobych Ivan Franko State Pedagogical University

\section{TRAINING OF A FUTURE PRIMARY SCHOOL TEACHER FOR TEACHING THE HEALTH BASICS SUBJECT}

This article considers the actual aspects of the training of students of pedagogical universities for teaching "Health basics" subject in elementary school, upbringing the pupils' valuable attitude to their own lives and conscious striving for healthy lifestyle. The role of the discipline "Methodology of study valeology, fundamentals of safety in elementary school" in the person-professional formation of future teachers, capable of forming health-saving competence in an efficient way regarding primary school pupils. Students should realize that the educational integrated discipline "Health basics" has an applied nature and complex structural organization, which includes informational, operational and motivational components. The emphasis is on the need for the students'ability of effective use of interactive technologies at the lessons of the health basics and in extracurricular work. The peculiarities of teaching the "Health basics" subject in primary school are analyzed, the information, provided concerning the experience of using the innovative approaches during the training of future teachers and the results of the questionnaire for students on the direction of training "Primary education" regarding their lifestyle. Among the negative aspects of the students' lifestyle were the following: hypodynamia, inappropriate nutrition, violation of sanitary and hygiene requirements regarding work and rest regime. It is shown that a teacher is the very person who can succeed in forming the health culture of primary school pupils and for whom the principles of healthy lifestyle became their own life principles.

Keywords: training; a primary school; health basics; health-saving competence; interactive technologies.

остановка проблеми. Несприятливі соціально-економічні та політичні умови сучасної України, важка екологічна ситуація, інформаційне перенасичення та інтенсифікація навчального процесу викликають тенденції до погіршення здоров’я 


\section{ПІДГОТОВКА МАЙБУТНЬОГО ВЧИТЕЛЯ ПОЧАТКОВОЇ ШКОЛИ ДО ВИКЛАДАННЯ ПРЕДМЕТА “ОСНОВИ ЗДОРОВ 'Я”}

дітей і учнівської молоді. За останнє десятиріччя значно збільшилася чисельність дітей, які мають хронічні захворювання та функціональні відхилення стану здоров'я [2, 54; 5, 373].

В таких умовах навчання людини відповідальному ставленню до власного здоров'я i здоров'я оточуючих як до найвищих індивідуальних і суспільних цінностей стає одним iз пріоритетних напрямів державної політики у галузі освіти. Посилення потреби у забезпеченні здоров'язбережувальної діяльності навчальних закладів зумовлюється також інтеграцією України у світовий освітній простір.

Актуальність проблеми формування, збереження та зміцнення здоров'я підростаючого покоління задекларовано у Національній стратегії розвитку освіти в Україні на 2012 - 2021 роки; Державній національній програмі “'Освіта (Україна XXI століття)”, Державній програмі “Здорова дитина на 2008 - 2017 роки"; Концепції Загальнодержавної програми “Здоров’я 2020: український вимір”, Концепції безперервного валеологічного виховання та освіти в Україні, наказах Управління освіти і науки "Про регіональну програму Національної мережі шкіл сприяння здоров’ю”, “Про заходи щодо розвитку духовності, захисту моралі та формуванні здорового способу життя громадян”, міжнародному проекті “Європейська мережа шкіл сприяння здоров’я” та інших.

Згідно з державними стандартами початкової освіти до базових навчальних планів було введено освітню галузь “ЗДоров’ я ф фізична культура“", яка реалізується окремими предметами: “Основи здоров’ я” та “Фізична культура”. У проекті нового державного стандарту початкової загальної освіти також значну увагу приділено збереженню здоров'я дитини та безпеці шкільного простору. Для цього визначено соціальну і здоров' язбережну галузь, метою якої є формування здорового способу життя та створення безпечних умов для фізичного та психоемоційного розвитку дітей. Школа має дати знання про здоров'я та безпеку, допомогти школярам оволодіти життєвими навичками здорової та безпечної поведінки.

Якісне викладання навчального предмета “Основи здоров'я” потребує особливої підготовленості майбутнього вчителя початкової школи, здатного ефективно вирішувати питання здоров'язбереження та здоров'яформування учнів.

Аналіз досліджень і публікацій. Теоретичні засади професійної підготовки майбутнього вчителя висвітлені в наукових доробках вітчизняних та зарубіжних учених, таких як:
А. Алексюк,Н. Волкова О. Дубасенюк, Л. Кондрашова, Н. Кузьміна, О. Кучерявий, О. Пєхота, І. Підласий, О. Савченко, С. Сисоєва, В. Сластьонін, С. Харченко, Л. Хомич та ін.

Наукові ідеї щодо підготовки фахівців валеологічного спрямування, зокрема майбутніх учителів основ здоров'я містяться у працях Ю. Бойчука, М. Гриньової, М. Гончаренко, І. Зенченкова, Г. Кондрацької, А. Радченко, Л. Сливки, С. Страшка, Л. Сущенко.

Практичні аспекти формування здорового способу життя молодших школярів представлені методистами: I. Бехом, Н. Бібік, Т. Бойченко, Т. Воронцовою, Н. Коваль, В. Пономаренко, С. Страшком.

Аналіз праць цих дослідників засвідчує, що формування здоров' язбережувальної компетентності учнів, ціннісного ставлення до власного здоров'я та здоров'я оточуючих стає дедалі частіше предметом психолого-педагогічних досліджень. Однак, проблема підготовки майбутніх вчителів початкової школи до викладання предмета “Основи здоров'я" потребує детальнішого розгляду як науковцями, так і практиками.

Мета статті - показати особливості підготовки майбутнього фахівця початкової школи до викладання предмета “Основи здоров'я”, формування здорового способу життя та зміцнення здоров'я молодших школярів.

Виклад основного матеріалу. До недавнього часу у вищій педагогічній школі України домінувала модель підготовки вчительських кадрів, що була спрямована на передачу студентам певного обсягу знань, умінь і навичок. Сьогодні вона втрачає свою актуальність. 3 огляду на суспільну потребу у творчих, всебічно освічених, компетентних фахівцях, здатних до самонавчання та самовдосконалення виникає необхідність зміни стратегічних цілей педагогічної освіти, зміщення акценту зі знань спеціаліста на його особистісні якості, що постають водночас і як мета, і як засіб його підготовки до майбутньої професійної діяльності [3, 41].

Одним із перспективних напрямів реформування освіти $€$ впровадження компетентнісно спрямованого підходу. Компетентністний підхід (знання заради вмінь) полягає у формуванні та розвитку життєвих навичок (англ. "life-skills approach" - підхід на основі життєвих навичок). На думку Л. Сливки, життєві навички - це здатність моделювати конкретні моделі поведінки. Навчання здійснюється на ситуаціях, близьких до реального життя. Метод розвитку життєвих навичок враховує не лише актуальні потреби і проблеми, а й ті, що незабаром виникнуть у зоні 


\section{ПІДГОТОВКА МАЙБУТНЬОГО ВЧИТЕЛЯ ПОЧАТКОВОӤ ШКОЛИ ДО ВИКЛАДАННЯ ПРЕДМЕТА “ОСНОВИ ЗДОРОВ' Я”}

їх найближчого розвитку. На відміну від багатьох педагогічних підходів, розвиток життєвих навичок має на меті позитивні зміни у поведінці учнів. Тому він передбачає зміни не лише у знаннях, а й у ставленнях і навичках, які стимулюватимуть бажані поведінкові зміни [6, 43].

Здоров'язбережувальна компетентність охоплює життєві навички, які сприяють усім складовим здоров'я. Рухова активність, загартування, здорове харчування, відсутність шкідливих звичок, дотримання санітарногігієнічних вимог, режиму праці та відпочинку сприятимуть фізичному здоров’ю. Соціальне здоров'я можливе за умов співробітництва та спільної діяльності, співчуття, ефективного спілкування, уміння розв'язувати конфлікти, протидіяти негативним соціальним впливам: погрозам, тиску, дискримінації.

До навичок, що сприяють духовному та психічному здоров'ю, можна віднести самоконтроль, самоусвідомлення та самооцінку, мотивацію успіху та тренування волі, аналіз проблем і прийняття рішень, визначення життєвих цілей та програм.

Підготовка майбугнього вчителя до формування здоров'язбережувальної компетенності молодших школярів є складовою професійного навчання. Саме готовність фахівця до діяльності зі збереження та зміцнення здоров'я свого та своїх вихованців визначає його статус професіонала i творчої особистості.

Значний внесок в особистісно-професійне становлення майбутніх педагогів робить навчальна дисципліна "Методика вивчення валеології, основ безпеки життєдіяльності у початковій школі", що викладається відповідно до вимог Державного стандарту підготовки вчителів початкової школи. Ця навчальна дисципліна у Дрогобицькому державному педагогічному університеті імені Івана Франка вивчається студентами четвертого курсу напряму підготовки 6.010102 "Початкова освіта" і має на меті підготувати студентів до організації та проведення занять з основ здоров'я, формування у молодших школярів свідомого ставлення до свого здоров' я, оволодіння життєвими навичками здорового способу життя та безпечної життєдіяльності.

Основні завдання навчальної дисципліни полягають у тому, щоб:

- дати майбутнім вчителям початкових класів необхідну теоретичнуі практичнупідготовку щодо формування здоров'язбережувальних компетенцій учнів на основі оволодіння ними знаннями про здоров’я та безпеку життєдіяльності;
- забезпечити студентів методичними знаннями і вміннями планування, організації та проведення занять 3 основ здоров'я у початковій школі;

- навчити студентів організовувати та проводити позакласну роботу, спрямовану на розвиток життєвих навичок учнів та збереження власного здоров'я;

- підготувати майбутніх вчителів до ефективного застосування сучасних технологій навчання здорового способу життя під час викладання учням початкової школи предмета “Основи здоров'я”;

- розвивати професійні якості студентів, здатних в сучасних умовах сприяти формуванню в учнів психологічної готовності адекватно діяти у разі наближення чи виникнення небезпек, вмінь та навичок свідомого прийняття рішень;

- підготувати студентів до сприяння поширенню серед дітей валеологічних цінностей, норм і правил здорового способу життя, їх фізичному, психічному, соціальному і духовному розвитку.

Дослідники вважають, що компонентами змісту підготовки студентів до формування в учнів здорового способу життя є система мотивів, знань і вмінь даної діяльності вчителя, відповідно до чого виділяють мотиваційний (цільова спрямованість особистості на діяльність 3 формування в учнів початкових класів здорового способу життя), змістовний (знання теорії та методики формування в учнів початкових класів здорового способу життя) та процесуальний (практичні вміння і навички формування в учнів початкових класів здорового способу життя) компоненти [5, 378].

У процесі опанування курсу “Методика вивчення валеології, основ безпеки життєдіяльності у початковій школі" студенти мають усвідомити, що навчальна інтегрована дисципліна “Основи здоров'я” має прикладний характер і складну структурну організацію, яка включає в себе такі компоненти: - інформаційний (поєднує в собі знання про усі складові здоров'я людини, способи його збереження та зміцнення, здоровий спосіб життя та безпеку життєдіяльності); - операційний (поєднує способи планування, засоби, методи і форми організації здоров' язбережувальної діяльності); - мотиваційний (поєднує знання основ здоров'я з ціннісними орієнтаціями на задоволення соціально значущих і особистісно орієнтованих потреб).

Результатом підготовки майбутніх фахівців до викладання основ здоров'я має стати сформованість у них готовності вирішувати 


\section{ПІДГОТОВКА МАЙБУТНЬОГО ВЧИТЕЛЯ ПОЧАТКОВОӤ ШКОЛИ ДО ВИКЛАДАННЯ ПРЕДМЕТА “ОСНОВИ ЗДОРОВ'Я”}

здоров'язбережувальні завдання початкової освіти 3 урахуванням конкретних умов та особистісного досвіду. Науковці визначають наступні основні функції такої готовності: спонукально-стимулююча, спрямована на формування усвідомленого інтересу студентів до здоров'язбережувального навчання майбутніх вихованців; гносеологічна, спрямована на пізнання здоров'язбережувального процесу як об'єкта проектування; проектувальна, що виявляється в операційному забезпеченні особистісно орієнтованого здоров'язбережувального навчально-виховного процесу; адаптаційна, що передбачає створення умов успішної роботи 3 підготовки до формування культури здоров'я школярів [1, 147].

Як показує практика, процес формування здоров'язбережувальної компетентності потребує обов'язкового поєднання інформаційного й мотиваційного компонентів із практичною діяльністю учнів. Оскільки навички набуваються в діяльності, через прийняття рішень та відпрацювання моделей поведінки, тому на заняттях з основ здоров'я слід використовувати інтерактивні, а не інформативні методи навчання. Саме інтерактивні технології навчання побудовані на постійній, активній та позитивній взаємодії усіх учасників навчального процесу. Організація інтерактивного навчання передбачає використання дидактичних і рольових ігор, моделювання життєвих ситуацій, створення проблемних ситуацій, дискусії в малих групах [3, 71]. Це дозволяє учням набути необхідного досвіду розв'язання проблем, навчає вільно висловлювати свої думки, толерантно ставитися до різних точок зору, розподіляти обов'язки в групі й приймати спільні рішення.

Майбутній вчитель повинен бути не просто ознайомлений з інтерактивними технологіями навчання, а й вміти ефективно їх застосовувати на уроках 3 основ здоров'я та в позакласній роботі. Для цього під час практичних занять 3 дисципліни "Методика вивчення валеології, основ безпеки життєдіяльності у початковій школі” доцільно у формі рольової гри (один зі студентів виступає в ролі вчителя, а інші - учнів) проводити демонстрацію фрагментів уроків із використанням інтерактивних технологій. Як з'ясувалося, студенти часто стикаються зі значними труднощами в процесі такого розігрування, не завжди вміють правильно підібрати та модифікувати ту чи іншу інтерактивну вправу відповідно до теми уроку та вікових особливостей молодших школярів. Для демонстрації студенти найчастіше обирають фронтальні технології інтерактивного навчання: “Мозковий штурм”, “Мікрофон”, "Незакінчені речення", які є для них найбільш зрозумілими та найпростішими у виконанні. Складнішими, проте цікавішими $є$ групові (кооперативні) технології, зокрема “Карусель”, “Акваріум”, “Ротаційні трійки”, “Ажурна пилка”, робота в малих навчальних групах, а також дискусійні технології: метод “Прес", “Обери позицію”, “Зміни позицію” та ігрові технології, зокрема "Рольова гра", "Імітаційна гра" тощо. Така практика через дію дозволяє виявити прогалини у підготовці до реалізації інтерактивних технологій навчання, глибше зрозуміти їх суть та стимулювати творчу активність студентів.

Окрім цього, на практичних заняттях студенти вчаться самостійно робити порівняльний аналіз підручників різних авторів з основ здоров'я, проводити валеохвилинки, складати задачі валеологічного змісту, укладати конспекти уроків. Студентам пропонується вибрати 3 навчальної програми 3 основ здоров'я, яка має концентричний спосіб побудови, дві наближені теми уроків, що вивчаються у різних класах, i підготувати методичні розробки цих уроків, причому одні розробки уроків повинні бути класичними, а інші - інноваційними. Це дає змогу студентам порівняти зміст обраного навчального матеріалу, зрозуміти особливість його вивчення у різні вікові періоди молодших школярів, а також проаналізувати ефективність використання інноваційних підходів у процесі формування основ здорового способу життя учнів. Такий підхід розвиває, на нашу думку, критичне мислення, творчість та ініціативність майбутніх вчителів початкової школи.

Однак, досягнути успіху у формуванні культури здоров'я молодших школярів може лише вчитель, для якого принципи здорового способу життя стали власними життєвими принципами.

Результати проведеного анкетування серед студентів четвертого курсу напряму підготовки “Початкова освіта" щодо їх способу життя показали, що лише $15 \%$ майбутніх вчителів систематично роблять ранкову зарядку, $10 \%$ загартовуються, 18\% відвідують спортивні секції, танцювальні гуртки чи займаються фізичними навантаженнями індивідуально. Потребує покращання якість та режим харчування опитаних студентів. Це стосується кратності та інтервалу прийому їжі, вживання рідких страв, сніданків перед навчальними заняттями тощо. Студенти в недостатній кількості споживають свіжі овочі і фрукти; багато споживаної ними їжі містить консерванти, ароматизатори, синтетичні 


\section{ПІДГОТОВКА МАЙБУТНЬОГО ВЧИТЕЛЯ ПОЧАТКОВОӤ ШКОЛИ ДО ВИКЛАДАННЯ ПРЕДМЕТА “ОСНОВИ ЗДОРОВ' Я"}

барвники, емульгатори тощо; у перервах між парами студенти харчуються не повноцінними стравами, а здобними булочками, солодощами, фаст-фудами. Занадто багато часу майбутні педагоги проводять за комп'ютерами, планшетами. Позитивним $\epsilon$ те, що всі респонденти не мають шкідливих звичок (тютюнопаління, вживання алкоголю чи наркотичних речовин). Отже, серед негативних сторін способу життя студентів найбільш поширеними виявились наступні: гіподинамія, нераціональне харчування, порушення санітарногігієнічних вимог щодо режиму праці та відпочинку.

За даними дослідників існує стійкий взаємозв'язок між ставленням вчителя до свого здоров'я, його потребою у веденні здорового способу життя, рівнем грамотності у питаннях відновлення всіх аспектів здоров'я і наданням відповідного виховного впливу на учнів. Чим нижчий рівень грамотності педагога в цих питаннях, тим менше він сам мотивований до ведення здорового способу життя, тим менше він зацікавлений уздоров' язбереженні школярів [4, 284].

Тому у вищих педагогічних навчальних закладах необхідно забезпечити не лише глибоке і усвідомлене засвоєння необхідних знань студентами 3 питань здоров'язбереження, а й свідомий вибір кожного 3 них громадських цінностей здорового способу життя і формування на їх основі стійкої, індивідуальної системи ціннісних орієнтацій, здатних мотивувати їх поведінку і діяльність.

Висновки. 3 огляду на суттєве підвищення рівня захворюваності зростаючого покоління проблема формування, збереження та зміцнення здоров'я молодших школярів $є$ надзвичайно актуальною. Вагому роль у вирішенні цієї проблеми відводиться інтегрованому навчальному предмету “Основи здоров'я”, якісне викладання якого потребує особливої підготовленості майбутнього вчителя початкової школи. Узагальненим результатом навчання основ здоров'я у початковій школі $\epsilon$ відповідний до віку рівень здоров'язбережувальної компетентності учнів. Підготувати фахівця, здатного ефективно вирішувати питання здоров'язбереження та здоров'яформування молодших школярів, покликаний курс "Методика вивчення валеології, основ безпеки життєдіяльності у початковій школі".

Про сформованість здоров' язбережувальної компетентності майбутнього педагога свідчить не лише володіння ним знаннями про здоров'я, здоровий спосіб життя, здоров'язбережувальні технології, але й усвідомлення цінності здоров'я, мотивація до здоров' язбережувальної діяльності, реалізація знань і вмінь на практиці.

Використання сучасних інноваційних технологій, зокрема технологій інтерактивного навчання, значною мірою підвищує ефективність навчального процесу, забезпечує оволодіння життєвими навичками здорового способу життя молодших школярів і виховання у них потреби в здоров’ї як важливої життєвої цінності.

У перспективі планується дослідження доцільності застосування у процесі підготовки майбутніх вчителів початкової школи до викладання основ здоров'я тренінгових форм роботи.

\section{ЛIТЕРАТУРА}

1. Диканова Е. Г. Подготовка будущего учителя к формированию культуры здоровья младшего школьника в условиях педколледжа: дисс. ... канд. пед. наук: 13.00.08 / Е. Г. Диканова. Волгоград, 2004. - 182 с.

2. Долинський Б. Т. Педагогічні основи підготовки майбутніх учителів початкової школи до валеологічного виховання молодших школярів / Б. Т. Долинський, Г. С. Писаренко, С. В. Бондар, Д. Д. Славов // Наука і освіта. - Одеса, 2014. №8. - С. 54-58.

3. Комар О. А. Теоретичні та методичні засади підготовки майбутніх учителів початкової школи до застосування інтерактивної технології: дис. ... д-ра пед.. наук: 13.00 .04 / О. А. Комар. - Умань, 2011. -512 c.

4. Коцур Н. І. Професійна підготовка майбутніх педагогів $з$ питань збереження та зміцнення здоров'я школярів / Н. І. Коцур, Л. П. Товкун // Освіта Регіону: Український науковий журнал. № 3. - К.: Університет “Україна”, 2013. - С. 282 286.

5. Радченя І.В. Підготовка майбутнього вчителя початкових класів до формування здорового способу життя молодших школярів / І. В. Радченя // Педагогіка формування творчої особистості у вищій і загальноосвітній школах. - Запоріжжя, 2015. - Вип. 45 (98.) - С. 373-380.

6. Сливка Л. Методика викладання основ здоров'я в початкових класах: [навч.-метод. посіб.] / Лариса Сливка. - Івано-Франківськ: HAIP, 2014. - 204 c.

\section{REFERENCES}

1. Dikanova, Ye. G. (2004). Podgotovka budushchego uchitelya $\mathrm{k}$ formirovaniyu kultury zdorovya mladshego shkolnika $\mathrm{v}$ usloviyakh pedkolledzha [The training of a future teacher for the 


\section{THE CREATIVE DEVELOPMENT SOFTWEAR OF VISUALART AT PRIMARY EDUCATION: THEORETICALASPECT}

forming of health preservance culture of the primary school pupil in the college curriculum]. Candidate's thesis. Volgograd, 182 p. [in Russian].

2. Dolynskyi, B. T., Pysarenk, H. S., Bondar, S. V. \& Slavov, D. D. (2014). Pedahohichni osnovy pidhotovky maibutnikh uchyteliv pochatkovoi shkoly do valeolohichnoho vykhovannia molodshykh shkoliariv [Pedagogical bases of the training of future teachers for the forming of health preservance culture of primary school pupils ]. Nauka i osvita. Odesa, no.8, pp. 54-58. [in Ukrainian].

3. Komar, O. A. Teoretychni ta metodychni zasady pidhotovky maibutnikh uchyteliv pochatkovoi shkoly do zastosuvannia interaktyvnoi tekhnolohii [Theoretical and methodological bases of the training of future teachers of primary school for application of interactive technology]. Doctor's thesis. Uman, 512 p. [in Ukrainian].

4. Kotsur, N.I. \& Tovkun, L.P. (2013). Profesiina pidhotovka maibutnikh pedahohiv z pytan zberezhennia ta zmitsnennia zdorovia shkoliariv [Professional training of future teachers for questions of preservance and improvement of pupils' health]. Osvita Rehionu: Ukrainskyi naukovyi zhurnal, no. 3. Kyiv: "University of Ukraine", pp. 282-286. [in Ukrainian].

5. Radchenia, I.V. (2015). Pidhotovka maibutnoho vchytelia pochatkovykh klasiv do formuvannia zdorovoho sposobu zhyttia molodshykh shkoliariv [The training of future teacher for forming of healthy life style of primary school pupils]. Pedahohika formuvannia tvorchoi osobystosti $u$ vyshchii $i$ zahalnoosvitnii shkolakh. Zaporizhzhia, vol. 45 (98), pp.373-380. [in Ukrainian].

6. Slyvka, L. (2014). Metodyka vykladannia osnov zdorovia $v$ pochatkovykh klasakh [Teaching methodology of health basics in primary schools]. Ivano-Frankivsk: NAIR, 204 p. [in Ukrainian].

Стаття надійшла до редакції 14.03.2018

UDC 37.036.372.87

DOI:

Viktoriya Chorna, Ph.D.(Pedagogy), Senior Lecturer of the Primary Education Department Tetyana Olishuk, Student Melitopol Bohdan Khmelmytskiy State Pedagogical University

\section{THE DEVELOPMENT OF CREATIVITY BY MEANS OF VISUALART AT PRIMARY SCHOOL: THEORETICAL ASPECT}

The article deals with the developmental recourses of visual art for primary school children's personality. The authors insists that the drawing lessons at school are an effective way for it. The formation of creative personality, the realization of natural inclinations and abilities in the educational process is a strategic priority for modern educational system in Ukraine. There are manys famous domestic scientists (such as I. Bekh, L. Vyhotskiy, S. Didenko, A. Leontyev and others) also prove it in their research work. The aim of this article is to find out the visual arts' creative and developmental resources of primary school pupils. There are analysis of the theoretical and historical aspects of this problem, turn the attention to the professional activities of educators and professional artists in this article.

Authors make a conclusion that further relevant is the search of new pedagogical technologies holistic development of the child's creative activity by means of art: kindergarten - elementary school - high school; study of the range of issues concerning artistic creativity of gifted children in the special educational institutions.

Keywords: the pupils of primary school; visual art; development recourses.

Вікторія Чорна, кандидат педагогічних наук, старший викладач кафедри початкової освіти Тетяна Оліщук, студентка Мелітопольського дерэсавного педагогічного університету імені Богдана Хмельниького

\section{РОЗВИТОК КРЕАТИВНОСТІ ЗАСОБАМИ МИСТЕЦТВА У ПОЧАТКОВІЙ ШКОЛІ: ТЕОРЕТИЧНИЙ АСПЕКТ}

Стаття пов 'язана з визначенням розвивального ресурсу уроків образотворчого мистеитва для формування особистості учня початкової школи. У статті подано глибокий аналіз теоретичного та історичного аспектів визначеної проблеми, авторами звернуто увагу на результати професійної діяльності не тільки педагогів, але й вітчизняних художників. Автори роблять висновок, що наразі необхідно шукати нові та адаптувати вже існуючі иляхи формування креативності у молодиих школярів засобами образотворчого мистецтва.

Ключові слова: молодші школярі; образотворче мистецтво; розвивальний ресурс.

Tntroduction. One of the priorities identified by the National Education Doctrine of Ukraine is the conditions' creation for education of the person capable to think creatively, to find innovative solutions, to flexibly respond to changes in the terms of all society spheres radical restructuring. In this regard 